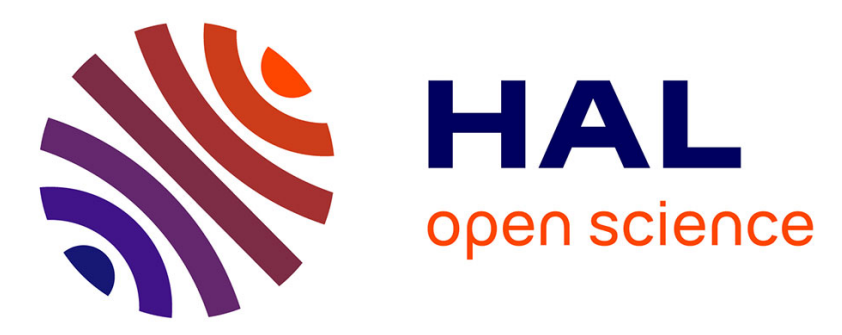

\title{
Cr, Ce, Nd: GGG crystal as active medium for efficient flashlamp pumped solid-state lasers
}

\author{
V. Sigachev, M. Doroshenko, V. Osiko, M. Timoshechkin
}

\section{To cite this version:}

V. Sigachev, M. Doroshenko, V. Osiko, M. Timoshechkin. Cr, Ce, Nd: GGG crystal as active medium for efficient flashlamp pumped solid-state lasers. Journal de Physique IV Proceedings, 1994, 04 (C4), pp.C4-598-C4-598. 10.1051/jp4:19944149 . jpa-00252604

\section{HAL Id: jpa-00252604 https://hal.science/jpa-00252604}

Submitted on 1 Jan 1994

HAL is a multi-disciplinary open access archive for the deposit and dissemination of scientific research documents, whether they are published or not. The documents may come from teaching and research institutions in France or abroad, or from public or private research centers.
L'archive ouverte pluridisciplinaire HAL, est destinée au dépôt et à la diffusion de documents scientifiques de niveau recherche, publiés ou non, émanant des établissements d'enseignement et de recherche français ou étrangers, des laboratoires publics ou privés. 


\title{
Cr, Ce, Nd:GGG crystal as active medium for efficient flashlamp pumped solid-state lasers
}

\author{
V.B. SIGACHEV, M.E. DOROSHENKO, V.V. OSIKO and M.I. TIMOSHECHKIN \\ General Physics Institute, Russian Academy of Sciences, Vavilov Street 38, Moscow 117942, Russia
}

The paper is the review of our recent results on investigation of spectroscopic and laser properties of $\mathrm{Cr}, \mathrm{Ce}, \mathrm{Nd}: \mathrm{GGG}$ crystal as active medium for efficient near infrared lasers.

The fluorescence spectra of $\mathrm{Nd}^{3+}$ ions in GGG have been studied in the wavelength region corresponding to ${ }^{4} \mathrm{~F}_{3} /\left.2^{-}{ }^{4}\right|_{11 / 2}$ and ${ }^{4} \mathrm{~F}_{3 / 2}-\left.{ }^{4}\right|_{13 / 2}$ transitions. Stimulated emission cross-sections of 1.062, 1.331 and $1.423 \mu \mathrm{m}$ lasing lines have been calculated. Comparison with the emission cross-section data for Nd:YAG crystal has been carried out.

Co-doping of Nd:GGG crystal with $\mathrm{Cr}^{3+}$ and $\mathrm{Ce}^{3+}$ ions allows to suppress stable color centers formation in the crystal after UV irradiation and increase lasing efficiency. Nonradiative energy transfer from $\mathrm{Cr}^{3+}$ ions to $\mathrm{Nd}^{3+}$ ions in GGG has been studied. The $80 \%$ quantum efficiency of this process was found to result in 1.5-2 times increase of lasing efficiency (compared to Nd:GGG) for flashlamp pumped operation.

The thermal lens and lasing properties of $\mathrm{Cr}, \mathrm{Ce}, \mathrm{Nd}$ : GGG rods have been studied in free-running mode at 1.062, 1.331 and $1.423 \mu \mathrm{m}$ wavelengths. The total efficiency more than $7 \%, 3 \%$ and $1.2 \%$ and average output power about $170 \mathrm{~W}, 70 \mathrm{~W}$ and $21 \mathrm{~W}$ were obtained for the single rod $(6.3 * 100 \mathrm{~mm})$ flashlamp pumped $\mathrm{Cr}, \mathrm{Ce}, \mathrm{Nd}$ :GGG laser at the 1.062, 1.331 and $1.423 \mu \mathrm{m}$ laser lines, respectively. The lasing properties of $\mathrm{Cr}, \mathrm{Ce}, \mathrm{Nd}$ :GGG are compared with that of Nd:YAG and Nd:YAP crystals in the same conditions. The advantages of $\mathrm{Cr}, \mathrm{Ce}, \mathrm{Nd}: \mathrm{GGG}$ crystals for the $1.331 \mu \mathrm{m}$ and eye-safe $1.423 \mu \mathrm{m}$ lasers are discussed.

The dual wavelength $\mathrm{Cr}, \mathrm{Ce}, \mathrm{Nd}$ :GGG laser operating simultaneously at 1.062 and $1.331 \mu \mathrm{m}$ in free-running and acousto-optic $\mathrm{Q}$-switching modes was realized and studied.

Lasing characteristics of $\mathrm{Cr}, \mathrm{Nd}$ :GGG crystals with stable $\mathrm{Cr}^{4+}$ centers will be presented and discussed. 